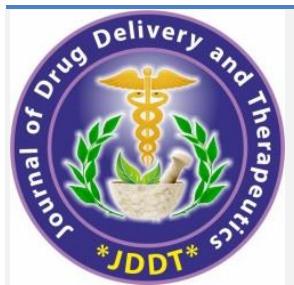

Open Access Full Text Article

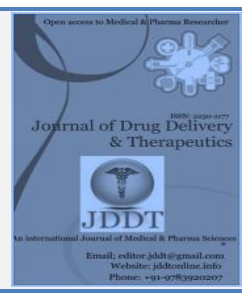

Research Article

\title{
Development and Validation of a RP-HPLC Method for the Simultaneous estimation of Amoxicillin, Omeprazole and Tinidazole in fixed dose combinations
}

\author{
Basant Lal ${ }^{* 1}$, Manish Jaimini1 ${ }^{1}$ Devesh Kapoor ${ }^{2}$ \\ ${ }^{1}$ Department of Pharmaceutical Sciences, Maharishi Arvind University, Mundiaramsar, Jaipur, Rajasthan-302041, India \\ 2 Department of Pharmacy, Dr. Dayaram Patel Pharmacy College, Bardoli, Gujarat-394601, India
}

Article Info:

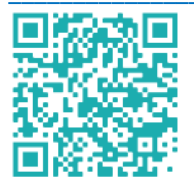

Article History:

Received 07 August 2021 Reviewed 29 September 2021

Accepted 04 October 2021

Published 15 October 2021

\section{Cite this article as:}

Lal B, Jaimini M, Kapoor D, Development and Validation of a RP-HPLC Method for the Simultaneous estimation of Amoxicillin, Omeprazole and Tinidazole in fixed dose combinations, Journal of Drug Delivery and Therapeutics. 2021; 11(5-S):57-62

DOI: http://dx.doi.org/10.22270/jddt.v11i5-S.5020

*Address for Correspondence:

Basant Lal, Research Scholar, Department of Pharmaceutical Sciences, Maharishi Arvind University, Mundiaramsar, Jaipur Rajasthan

\section{Abstract}

New liquid chromatographic technique was established for the simultaneous estimation of tinidazole, omeprazole and amoxicillin in the fixed dose combination (HP-KIT by Sun Pharma). RP-HPLC elution has performed by using the Phenomenex Luna column ( $250 \mathrm{~mm} \mathrm{x}$ $4.6 \mathrm{~mm}$ ) having internal diameter and the packing material of size $5 \mu \mathrm{m}$ ) in isocratic mobile phase of solution A: acetonitrile at a ratio of $80: 20 \mathrm{v} / \mathrm{v}$ (Solution A consists of Buffer: Acetonitrile: Methanol: Triethylamine in the ratios of 68:22:10:0.01 respectively). The selected flow rate was kept as $1 \mathrm{ml} / \mathrm{min}$ and selected wavelength was $230 \mathrm{~nm}$ was for detection of the drugs in UV detector. As per the ICH guidelines, the method validation was carried out. Moreover, the different parameters of method such as precision, specificity, linearity, robustness and accuracy were established. The time of retention for the tinidazole, amoxicillin, and omeprazole were 4.021 2.324, and 7.332 minutes respectively. The RP-HPLC approach was robust and accurate, so it is appropriate for repetitive assay of drugs and quality control. This method is effectively used for the assessment of marketable dosage form preparation.

Keywords: RP-HPLC, Amoxicillin, Tinidazole, Omeprazole, Method Development, Method Validation.

\section{INTRODUCTION:}

Helicobacter pylorus which is a gram-negative bacterium mostly found in the stomach. It was acknowledged in 1982 by Australian scientists Robin Warren and Barry Marshall. The researchers found that this bacterium was present in people suffering from gastric ulcers and chronic gastritis. Its presence was also noticed in patient of stomach cancer and duodenal ulcers. The stomach and duodenal linings was given much harm by the $\mathrm{H}$. pylori harm due to different mechanisms. These ulcers instigated by the H. Pylori are treated by using the different combination of drugs, like proton pump inhibitor (PPIs) drug combined with two antimicrobials drugs, such as amoxicillin and tinidazole.

\section{Chemical Structure of Omeprazole:}<smiles>COc1ccc2[nH]c(S(=O)Cc3ncc(C)c(OC)c3C)nc2c1</smiles>

Chemically omeprazole is recognized as 5-methoxy-2-[[(4methoxy-3, 5- dimethyl-2-pyridinyl) methyl] sulfinyl] benzimidazole. It is formally listed in BP2011 and USPXXXII. Omeprazole is PPIs, mostly employed in treatment of peptic ulcer disorder, ulceration associated with NSAID, in disease related to gastro-esophageal reflux and also in ZollingerEllison syndrome. A literature survey shown that estimation of omeprazole performed in pharmaceuticals by using High performance liquid chromatography ${ }^{1-3}$.

\section{Structure of Tinidazole:}<smiles>CCS(=O)(=O)CCn1c([N+](=O)[O-])cnc1C</smiles>

Tinidazole is chemically recognized as 1-(2-ethyl-sulphonyl ethyl)-2- methyl-5-nitroimidazole. It is official published in BP 2011 and USP XXXII. Omeprazole has significant activity 
against protozoa anaerobic and bacteria. It is used to eradicate $\mathrm{H}$. pylori in peptic ulcer disease with other proton pump inhibitor and antimicrobials. The estimation can be done through HPLC ${ }^{4-6}$

\section{Structure of Amoxicillin:}<smiles>C[C@@H](C(=O)O)N1C(=O)[C@@H](NC(=O)C(N)c2ccc(O)cc2)SC1(C)C</smiles>

Amoxicillin trihydrate chemically recognized as [2S$\left.\left[2 \mathrm{a}, 5 \mathrm{a}, 6 \mathrm{a}^{\wedge}(\mathrm{S})\right]\right]-6-[[$ Amino(4-hydroxyphenyl)acetyl]amino]-

3,3 dimethyl-7-oxo-4-thia-1-azabicyclo is the most extensively used $\beta$-lactam antibiotic to treat bacterial infections of ear, nose, throat, skin and lower respiratory tract due to susceptible microorganisms. It has significant absorption ability than other $\beta$-lactam antibiotics. The marketed formulations of amoxicillin are capsules, suspensions, tablets and injectable solutions. The combination drugs of Amoxicillin enhance the antibacterial effect and bacterial resistance. In literature, numerous analytical techniques have been employed for quantitative determination of amoxicillin by HPLC7-10.

Till date only one RP-HPLC method has been reported by Kasnia et $\mathrm{al}^{11}$ for the simultaneous estimation of these three drugs. This estimation was done for the microsphere formulation. So, it is a prerequisite to create a validated method using RP-HPLC to estimate the three drugs content in tablet/capsule formulation.

\section{MATERIALS AND METHODS}

\section{Instrumentation and Equipment:}

There is the establishment of analytical method and validation was done on the HPLC (Make \& Model: Agilent 1220 with UV Detector) is equipped with degasser, solvent delivery pump, using Software (Openlab®).

The elution of RP-HPLC was performed employing Phenomenex Luna column (internal diameter of $250 \times 4.6$ $\mathrm{mm}$ and the packing material having size of $5 \mu \mathrm{m}$ ) and solution A with isocratic mobile phase: acetonitrile at a ratio of $80: 20 \mathrm{v} / \mathrm{v}$ (The pH was accustomed to 6.7 by the help of orthophosphoric acid). For detection of the drugs, flow rate was $1 \mathrm{~mL} / \mathrm{min}$ and UV detector wavelength was fixed at 230 nm.

\section{Reagents and Chemicals}

Omeprazole, Tinidazole and amoxicillin were the gifted samples obtained from Uttranchal Research and Testing laboratory, Uttrakhand. Infrared Spectroscopy (IR) and Mass Spectroscopy were employed for the characterization of these samples to examine the purity level.

RANKEM Chemicals has supplied the AR grade chemicals which are orthophosphoric acid (OPA), potassium dihydrogen phosphate, triethylamine, methanol and HPLC grade acetonitrile. Milli- $Q$ water purification system was used for generation of water which was used during analysis (Make \& Model: MILLIPORE / Integral 5).

\section{Methods}

\begin{tabular}{|l|l|}
\hline \multicolumn{2}{|l|}{ Chromatographic conditions } \\
\hline Column & $\begin{array}{l}\text { Phenomenex Luna C18, column }(250 \mathrm{~mm} \mathrm{x} \\
4.6 \mathrm{~mm}), 5 \mu \mathrm{m}\end{array}$ \\
\hline Mobile phase & $\begin{array}{l}\text { Solution-A: Acetonitrile: Buffer: Methanol: } \\
\text { Triethylamine (Ph 6.7) in the ratio of } \\
22: 68: 10: 0.01 \\
\text { Solution A: Acetonitrile (80:20) v/v }\end{array}$ \\
\hline Detector & UV detector \\
\hline Flow rate & $1 \mathrm{ml} / \mathrm{min}$ \\
\hline Wavelength & $230 \mathrm{~nm}$ \\
\hline $\begin{array}{l}\text { Injection } \\
\text { Volume }\end{array}$ & $20 \mu \mathrm{L}$ \\
\hline Temperature & $35^{\circ} \mathrm{C}$ \\
\hline Diluent & Mobile phase \\
\hline
\end{tabular}

\section{Preparation of Standard Solution:}

The stock solutions were formulated by dissolving Omeprazole $(25 \mathrm{gm})$ in $25 \mathrm{ml}$ flask, followed by addition of $10 \mathrm{ml}$ of diluent and mix well. Make the volume. Take $1 \mathrm{ml}$ of solution from this solution in $50 \mathrm{ml}$ flask. Add $31 \mathrm{mg}$ of amoxicillin and $25 \mathrm{mg}$ of tinidazole. Mix well with diluent and finally make the volume to prepare concentrations of 20 $\mu \mathrm{g} / \mathrm{mL}$ for Omeprazole and $500 \mu \mathrm{g} / \mathrm{mL}$ for Amoxicillin \& Tinidazole respectively.

\section{Preparation of Sample Solution:}

The sample solutions were formulated by dissolving $1 / 10$ of average weight of drugs in $50 \mathrm{ml}$ flask and mix well with diluents to prepare concentrations of $500 \mu \mathrm{g} / \mathrm{mL}$ for Amoxicillin \& Tinidazole and $20 \mu \mathrm{g} / \mathrm{mL}$ for Omeprazole respectively.

\section{Method Validation}

As per ICH Q2 guidelines, linearity, suitability, accuracy, specificity, precision, LOD/ LOQ and robustness were considered for validation of developed method 12 .

\section{Specificity and selectivity}

The established method was found to be suitable for omeprazole, amoxicillin and tinidazole, as the blank solution injection has given the confirmation of absence of interfering peak at RT examined substance at $230 \mathrm{~nm}$ wavelength. The outcome obtained demonstrates that no interference was exhibited from other material in the established method and therefore it confirms the established method specificity ${ }^{12}$.

\section{RESULTS}

\section{System Suitability}

The test performed for suitability of system is an essential part of method development, were employed to confirm acceptable chromatographic system performance. The evaluation for retention time (RT), peak asymmetry, tailing factor, and theoretical plates (T) were performed. The outcome are summarised below in Table 1 
Table 1: System suitability parameters of Amoxicillin, tinidazole and omeprazole

\begin{tabular}{|l|l|l|l|l|l|}
\hline $\begin{array}{l}\text { Sr. } \\
\text { No. }\end{array}$ & Property & Amoxicillin & Tinidazole & Omeprazole & Acceptance criteria \\
\hline 1. & Retention Time (RT) & 2.228 & 4.112 & 7.256 & - \\
\hline 2. & Tailing factor (T) & 1.10 & 1.21 & 1.01 & NMT 2.0 \\
\hline 3. & Theoretical plates (N) & 6337 & 4265 & 3832 & NLT 2000 \\
\hline
\end{tabular}

From the above data it was established that that all the suitability parameters of system were within the limit for developed method.

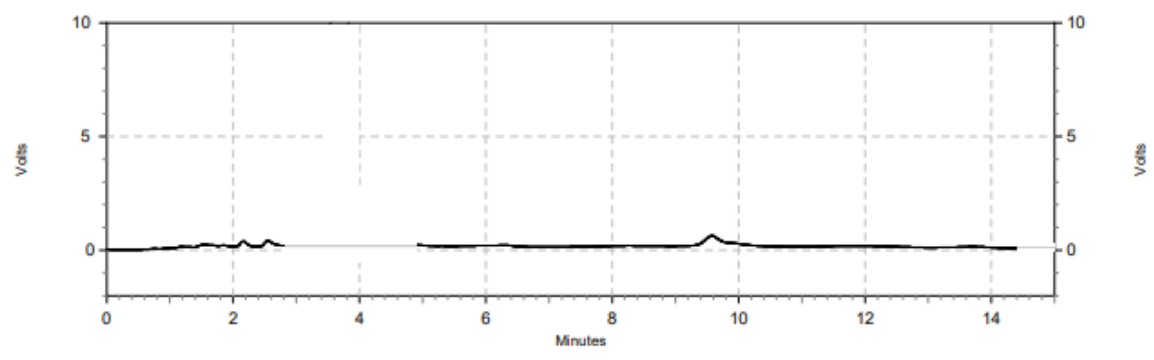

Chromatogram: Blank

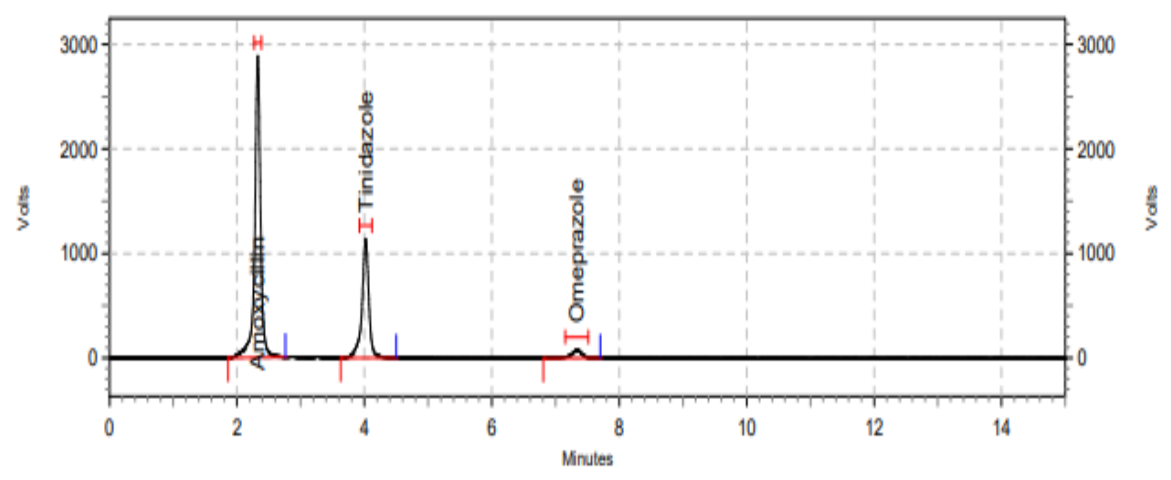

Chromatogram: Standard

\section{Linearity and Range}

The developed method linearity proves the method ability to deliver an outcome which is directly proportional to analyte concentration in the sample. The amount of amoxicillin, tinidazole and omeprazole were made for linearity in the 80$120 \%$ range. The amoxicillin, tinidazole and omeprazole amount in five dissimilar concentrations are $80 \%, 90 \%$, $100 \%, 110 \%$ and $120 \%$ of working standard respectively. The graph was plotted between area of peak and concentrations. The omeprazole, amoxicillin and tinidazole exhibited good correlation coefficients $\left(\mathrm{R}^{2}=0.9992,0.9982\right.$, and 0.9995 ) and the planned method was linear in $80-120 \%$ concentration range.

Table 2: Linearity of Amoxicillin, Omeprazole and Tinidazole

\begin{tabular}{|c|c|c|c|c|c|c|c|c|}
\hline \multirow{2}{*}{$\begin{array}{l}\text { S. } \\
\text { No. } \\
1\end{array}$} & \multirow{2}{*}{$\begin{array}{l}\text { Compound } \\
\text { Amoxicillin }\end{array}$} & \multicolumn{6}{|c|}{ Values of $\mathrm{X}$ and $\mathrm{Y}$ Variables } & \multirow{2}{*}{$\begin{array}{l}\begin{array}{l}\text { Correlation } \\
\text { co-efficient }\end{array} \\
0.9982\end{array}$} \\
\hline & & Variable & 1 & 2 & 3 & 4 & 5 & \\
\hline & & $\mathbf{X}$ & 400 & 450 & 500 & 550 & 600 & \\
\hline & & $\mathbf{Y}$ & 306529813 & 336208695 & 365098652 & 388299753 & 415609155 & \\
\hline \multirow[t]{2}{*}{2} & Tinidazole & $\mathbf{X}$ & 400 & 450 & 500 & 550 & 600 & \multirow[t]{2}{*}{0.9995} \\
\hline & & $\mathbf{Y}$ & 114987563 & 128677481 & 143320695 & 158340861 & 173826962 & \\
\hline \multirow[t]{2}{*}{3} & Omeprazole & $\mathbf{X}$ & 16 & 18 & 20 & 22 & 24 & \multirow[t]{2}{*}{0.9992} \\
\hline & & $\mathbf{Y}$ & 11975684 & 13659318 & 15030951 & 16632982 & 18237528 & \\
\hline
\end{tabular}

Note: $\mathrm{X}$ is the concentration of the respective component in $\mu \mathrm{g} / \mathrm{mL}$. Y is the peak response of the respective component in area counts. 


\section{Linearity Curve}

Calibration curve was plotted between peak area and different concentrations. The outcomes were noted for equation of line and correlation co-efficient were also calculated.
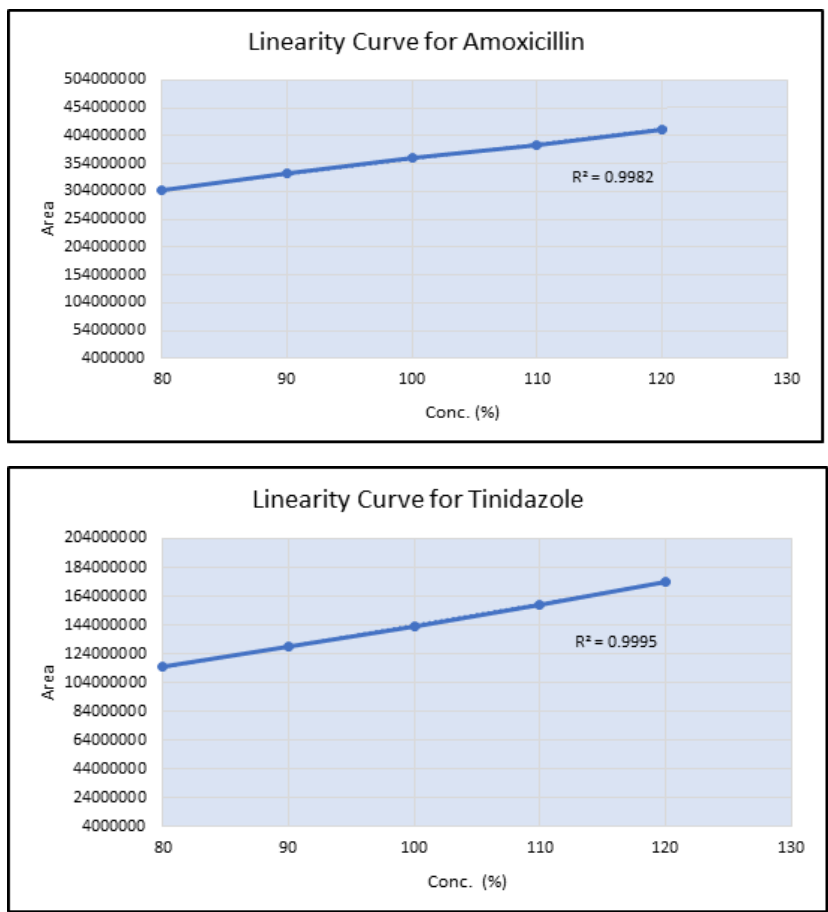

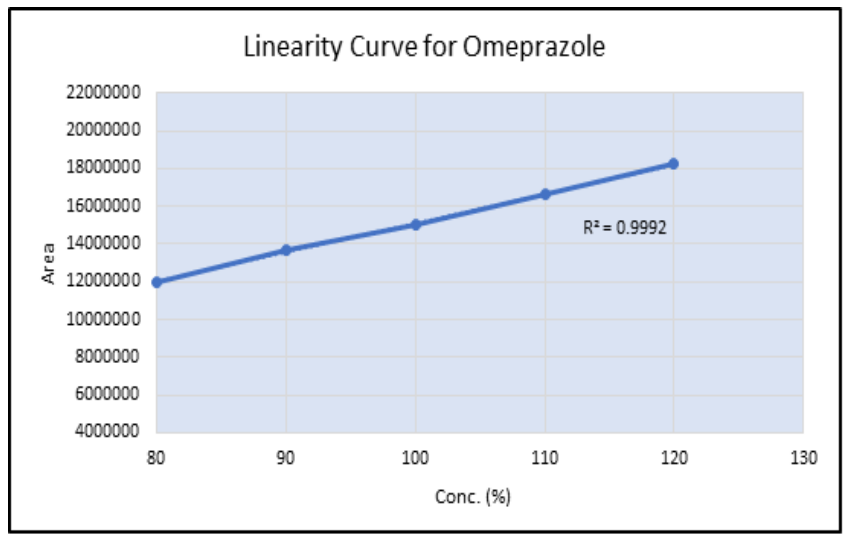

\section{Precision}

The precision exhibits the closeness between the series of measurements. The developed method precision was established by method precision and system precision. A homogenous sample concentration of $20 \mu \mathrm{g} / \mathrm{mL}$ for Omeprazole and $500 \mu \mathrm{g} / \mathrm{mL}$ for Amoxicillin \& Tinidazole were prepared under recommended conditions and determination was performed as well. The outcomes are mentioned in the form of standard deviation (SD) and RSD value. Table 3 and 4 discloses the outcome of method precision and system precision respectively and the developed method is extremely precise as the value for $\%$ RSD is less than $2 \%$.

Table 3: Calculation of \%RSD for Amoxicillin, omeprazole and tinidazole (System Precision)

\begin{tabular}{|c|c|c|c|c|c|c|c|c|c|c|}
\hline \multirow{2}{*}{$\begin{array}{l}\text { S. } \\
\text { N } \\
\text { o }\end{array}$} & \multirow[t]{2}{*}{ Compound } & \multicolumn{6}{|c|}{ No. of Injections } & \multirow[t]{2}{*}{ Mean } & \multirow[t]{2}{*}{ S.D. } & \multirow{2}{*}{$\begin{array}{l}\text { \%RS } \\
\text { D }\end{array}$} \\
\hline & & 1 & 2 & 3 & 4 & 5 & 6 & & & \\
\hline 1 & $\begin{array}{l}\text { Reference } \\
\text { Standard } \\
\text { Amoxicillin }\end{array}$ & $\begin{array}{l}3106195 \\
62\end{array}$ & $\begin{array}{l}31064582 \\
1\end{array}$ & $\begin{array}{l}31068754 \\
9\end{array}$ & $\begin{array}{l}31067985 \\
2\end{array}$ & $\begin{array}{l}31070559 \\
3\end{array}$ & $\begin{array}{l}31065298 \\
4\end{array}$ & $\begin{array}{l}31066522 \\
7\end{array}$ & $\begin{array}{l}31474.91 \\
8\end{array}$ & 0.010 \\
\hline 2 & $\begin{array}{l}\text { Reference } \\
\text { Standard } \\
\text { Tinidazole }\end{array}$ & $\begin{array}{l}1455964 \\
31\end{array}$ & $\begin{array}{l}14531956 \\
6\end{array}$ & $\begin{array}{l}14574824 \\
1\end{array}$ & $\begin{array}{l}14603218 \\
4\end{array}$ & $\begin{array}{l}14631854 \\
7\end{array}$ & $\begin{array}{l}14552471 \\
8\end{array}$ & $\begin{array}{l}14575661 \\
5\end{array}$ & $\begin{array}{l}363929.3 \\
7\end{array}$ & 0.250 \\
\hline 3 & $\begin{array}{l}\text { Reference } \\
\text { Standard } \\
\text { Omeprazole }\end{array}$ & $\begin{array}{l}1571596 \\
2\end{array}$ & 15748752 & 15705487 & 15774851 & 15795822 & 15739856 & 15746788 & $\begin{array}{l}34350.51 \\
7\end{array}$ & 0.218 \\
\hline
\end{tabular}

Table 4: Calculation of \%RSD for Amoxicillin, omeprazole and tinidazole and (Method Precision)

\begin{tabular}{|c|c|c|c|c|c|c|c|c|c|c|}
\hline \multirow{2}{*}{$\begin{array}{l}S . \\
\text { No }\end{array}$} & \multirow[t]{2}{*}{ Compound } & \multicolumn{6}{|c|}{ No. of Injections } & \multirow[t]{2}{*}{ Mean } & \multirow[t]{2}{*}{ S.D. } & \multirow{2}{*}{$\begin{array}{l}\text { \%RS } \\
\text { D }\end{array}$} \\
\hline & & 1 & 2 & 3 & 4 & 5 & 6 & & & \\
\hline 1 & $\begin{array}{l}\text { Sample } \\
\text { Amoxicillin }\end{array}$ & $\begin{array}{l}365098 \\
652\end{array}$ & $\begin{array}{l}3648951 \\
62\end{array}$ & $\begin{array}{l}36513247 \\
6\end{array}$ & $\begin{array}{l}36519841 \\
1\end{array}$ & $\begin{array}{l}36586232 \\
5\end{array}$ & $\begin{array}{l}36571064 \\
8\end{array}$ & $\begin{array}{l}36531627 \\
9\end{array}$ & 381069.7 & 0.104 \\
\hline 2 & $\begin{array}{l}\text { Sample } \\
\text { Tinidazole }\end{array}$ & $\begin{array}{l}143320 \\
695\end{array}$ & $\begin{array}{l}1432155 \\
48\end{array}$ & $\begin{array}{l}14339568 \\
2\end{array}$ & $\begin{array}{l}14348607 \\
1\end{array}$ & $\begin{array}{l}14396584 \\
2\end{array}$ & $\begin{array}{l}14389524 \\
3\end{array}$ & $\begin{array}{l}14354651 \\
4\end{array}$ & $\begin{array}{l}311250.4 \\
6\end{array}$ & 0.217 \\
\hline 3 & $\begin{array}{l}\text { Sample } \\
\text { Omeprazole }\end{array}$ & $\begin{array}{l}150309 \\
51\end{array}$ & $\begin{array}{l}1502547 \\
6\end{array}$ & 15036741 & 15037245 & 15040887 & 15039604 & 15035151 & $\begin{array}{l}5846.186 \\
2\end{array}$ & 0.039 \\
\hline
\end{tabular}

Mean represents the average values of six replicates analysis. SD is the standard deviation calculated on the six replicates. RSD is the relative standard deviation. 
Table 5: System Precision and Method precision

\begin{tabular}{|l|l|l|}
\hline Precision & Drug & \% RSD \\
\hline System precision & Amoxicillin & 0.011 \\
\hline Method precision & Amoxicillin & 0.106 \\
\hline System precision & Tinidazole & 0.255 \\
\hline Method precision & Tinidazole & 0.221 \\
\hline System precision & Omeprazole & 0.209 \\
\hline Method precision & Omeprazole & 0.045 \\
\hline
\end{tabular}

\section{Accuracy}

Accuracy is also known as trueness or recovery. The accuracy was checked by using $80 \%, 120 \%$ and $100 \%$ of working strength of amoxicillin, omeprazole and tinidazole. Each level of solution was prepared in duplicate and analysis is done as per the above method. This is usually mentioned in the form of SD and RSD. The outcome expressed that the value of $\%$ RSD is less than $2 \%$. The $\%$ recovery results are mentioned in Table 6.

Table 6: Summary of assay of Amoxicillin, omeprazole and tinidazole

\begin{tabular}{|c|c|c|c|c|}
\hline S. No. & Level & Compound & $\begin{array}{l}\text { \% Average } \\
\text { Assay }\end{array}$ & \%RSD \\
\hline \multirow[t]{3}{*}{1} & \multirow[t]{3}{*}{$80 \%$} & Amoxicillin & 99.49 & 0.09 \\
\hline & & Tinidazole & 99.83 & 0.16 \\
\hline & & Omeprazole & 99.12 & 0.19 \\
\hline \multirow[t]{3}{*}{2} & \multirow[t]{3}{*}{$100 \%$} & Amoxicillin & 99.96 & 0.11 \\
\hline & & Tinidazole & 99.50 & 0.25 \\
\hline & & Omeprazole & 99.26 & 0.10 \\
\hline \multirow[t]{3}{*}{3} & \multirow[t]{3}{*}{$120 \%$} & Amoxicillin & 99.04 & 0.15 \\
\hline & & Tinidazole & 99.01 & 0.26 \\
\hline & & Omeprazole & 99.80 & 0.24 \\
\hline
\end{tabular}

Assay values of tinidazole were found of in the range of 99.11-99.89, amoxicillin in the range of $\% 99.14-99.86 \%$ and omeprazole in the range of 99.09-99.79\%. Moreover, amoxicillin \% RSD assay values were in the range of 0.08$0.22 \%$, tinidazole in the range of $0.15-0.24 \%$ and omeprazole in the range of $0.11-0.25 \%$. The study confirms that the developed method is precise for the estimation of amoxicillin, tinidazole and omeprazole assay over the range of $80-120 \%$ of target concentration.

\section{LOD and LOQ (Limit of Detection and Limit of Quantification)}

Limit of detection (LOD) and Limit of Quantification (LOQ) exhibits information related to the analyte concentration that yields signal-to-noise around 1 to 10 . The serial dilutions are fabricated from the amoxicillin, tinidazole and omeprazole solution for estimation of LOQ and LOD values respectively. The prepared samples were injected into the HPLC system and blank and sample signals were compared for LOD and LOQ calculation. As per the parameters mentioned earlier, LOD and LOQ were calculated for amoxicillin, omeprazole and tinidazole detected values were
$9 \mu \mathrm{g} / \mathrm{ml}, 10 \mu \mathrm{g} / \mathrm{ml}, 27 \mu \mathrm{g} / \mathrm{ml} 2 \mu \mathrm{g} / \mathrm{ml}$ and $0.7 \mu \mathrm{g} / \mathrm{ml}, 25$ $\mu \mathrm{g} / \mathrm{ml}$, respectively.

\section{Robustness}

The robustness of the method was carried out by doing little deliberate changes in the current developed HPLC method process parameters. These parameters include mobile phase flow rate variations, the minute variation in detector wavelength and variation in the proportion of acetonitrile and buffer. Additionally single concentrations of amoxicillin, omeprazole and tinidazole were employed for verification of robustness parameters. The minor variation of parameters can do some noteworthy changes in the RSD values and peak area. This study recapitulated that the developed method is robust under small changes like \pm 2 wavelengths, $\pm 10 \%$ flow rate and $\pm 10 \%$ surge and decline in mobile phase and at the diverse column (Inertsil ODS-3, column $(250 \mathrm{mmx} 4.6 \mathrm{~mm}), 5$ micron. There is no significant change in recovery of omeprazole, amoxicillin and tinidazole. The \% RSD values shown in the Table 7 exhibited that insignificant changes were seen after doing the deliberate changes. So, this study describes that the developed method is robust in nature.

Table 7: Robustness Data

\begin{tabular}{|l|l|l|}
\hline Drug & Parameters & \% RSD \\
\hline $\begin{array}{l}\text { Amoxicillin, } \\
\text { tinidazole and } \\
\text { omeprazole }\end{array}$ & Wavelength minus & 0.003 \\
\cline { 2 - 3 } & Wavelength plus & 0.002 \\
\cline { 2 - 3 } & Flow minus & 0.004 \\
\cline { 2 - 3 } & Flow plus & 0.002 \\
\cline { 2 - 3 } & $\begin{array}{l}\text { Mobile phase ratio } \\
\text { change }\end{array}$ & 0.003 \\
\cline { 2 - 3 } & Column Change & 0.001 \\
\cline { 2 - 3 } & Temperature minus & 0.004 \\
\cline { 2 - 3 } & Temperature plus & 0.005 \\
\hline
\end{tabular}

\section{DISCUSSION}

Trial and error method was employed and subsequently a random number of trials with different, mobile phases were employed but the finest separation of Amoxicillin, omeprazole and tinidazole was present in the Solution A: Acetonitrile in the ratio of 20: 80 (in Isocratic mode). Finally, best outcomes were attained with the flow rate programming of chosen mobile phase for the estimation purpose of all the three drugs. Mobile phase was continued for 60 seconds to $15 \mathrm{~min}$ with a of $1 \mathrm{ml} / \mathrm{min}$ flow rate and detection was done at $230 \mathrm{~nm}$ by using UV detector.

The validation of fabricated and the optimized method of RPHPLC was done according to the ICH guidelines with reference to the diverse parameters such as limit of detection (LOD) linearity, limit of quantification (LOQ), accuracy, precision, and specificity. All the results obtained were found in accordance with ICH guideline.

\section{CONCLUSION}

Agilent 1220 LC system was used for the validation reason of the fabricated and optimized liquid chromatographic method for simultaneous assessment of amoxicillin, omeprazole and tinidazole in HP kit combination. The approach for simultaneous determination of tablet/capsule dosage form has not been mentioned earlier. So, the recent method is novel for these drugs determination at a single wavelength 
which is $230 \mathrm{~nm}$, along with $20 \mu \mathrm{L}$ injection volume and by employing the Phenomenex Luna C18 $5 \mu \mathrm{m} 4.6^{*} 150 \mathrm{~mm}$ column. The process is very simple, sensitive and fast as well as accurate, precise, linear and robust which is in accordance of guidelines of ICH. The experimentation work demonstrates that the method development of liquid chromatographic approach exhibited good linearity, resolution, and RSD values which is less than $2 \%$, which proves that simultaneous determination of Amoxicillin, omeprazole and tinidazole can be done suitably by this developed method.

\section{ACKNOWLEDGEMENT}

Authors are highly thankful to the services provided by the Uttrakhand Research and Testing Laboratory, Uttrakhand.

\section{REFERENCES}

1. El-Sherif ZA, Mohamed AO, El-Bardicy MG, El-Tarras MF. Reversed-phase high performance liquid chromatographic method for the determination of lansoprazole, omeprazole and pantoprazole sodium sesquihydrate in presence of their Acid induced degradation products, J Chem Pharm Bull (Tokyo) 2006; 54(6):814-8. https://doi.org/10.1248/cpb.54.814

2. Ariane P, Rafael N, Bruno R, Marcos AS. Fabio S. Murakami Cruz Pereira Valente Silva Development and validation of a RP-HPLC method to quantify omeprazole in delayed release tablets, J of Liquid Chromatography and Related Technologies 2007; 30(1):113-21. https://doi.org/10.1080/10826070601034485

3. Darwish KM, Salama I, Mostafa S, El-Sadek M. RP-HPLC/precolumn derivatization for analysis of omeprazole, tinidazole, doxycycline and clarithromycin, J Chromatogr Sci 2013; 51(6):566-76. https://doi.org/10.1093/chromsci/bms167

4. Pasha K, Ali A, Bana S, Humair S, J. Reverse phase-HPLC method for the analysis of tinidazole in pharmaceutical dosage form \& bulk drug, J Int Pharm Sci Acta Pharm 2010; 2(2):46-7.
5. Sneha JK, Nirav PB, Parag PR, Nikita PN, Hemant DT, Iosr. Development and validation of stability indicating method for simultaneous estimation of ciprofloxacin $\mathrm{HCl}$ and tinidazole using RP-UPLC method, J Acta Pharm 2012; 2(5):12-9. https://doi.org/10.9790/3013-25401219

6. Pasha K, Ali A, Bana S, Humair S, Reverse-phase-HPLC method for the analysis of tinidazole in pharmaceutical dosage form \& bulk drug, J Int Pharm Sci Acta Pharm 2010; 2(2):46-7.

7. Beg, S., Kohli, K., Swain, S., Hasnain, M.S.; Development and validation of RP-HPLC method for quantitation of amoxicillin trihydrate in bulk and pharmaceutical formulations using BoxBehnken experimental design, Journal of Liquid Chromatography \& Related Technologies, 2012; 35:393-406. https://doi.org/10.1080/10826076.2011.601493

8. Ashnagar, A., Naseri, N.G.; Analysis of three penicillin antibiotics (ampicillin, amoxicillin and cloxacillin) of several Iranian pharmaceutical companies by HPLC, E-Journal of Chemistry, (2007); 4:536-545. https://doi.org/10.1155/2007/480907

9. Samanidou, V.F., Evaggelopoulou, E.N., Papadoyannis, I.N.; Development of a validated HPLC method for the determination of four penicillin antibiotics in pharmaceuticals and human biological fluids, Journal of Separation Science, 2006; 29:1550 1560. https://doi.org/10.1002/jssc.200600081

10. Foulstone, M., Reading, C.; Assay of amoxicillin and clavulanic acid, the components of Augmentin, in biological fluids with high-performance liquid chromatography, Antimicrobial Agents Chemotherapy, 1982; 22:753-762. https://doi.org/10.1128/AAC.22.5.753

11. Kasnia V, Kumar MS, Mahadevan N, Int J. Simultaneous estimation of amoxicillin, tinidazole and omeprazole in microsphere formulation by RP-HPLC, recent Adv Pharm Res. J Acta Pharm 2012; 2(2):78-83.

12. Chaudhary A, Dhaiya M, Tyagi S, Mittal S, Method Development and Validation of Polmacoxib in Capsule Dosage Form by RPHPLC, Journal of Drug Delivery and Therapeutics. 2021; 11(4S):59-63. https://doi.org/10.22270/jddt.v11i4-S.4984 